\title{
Studies of stability and characterization this enzyme bromelain in pineapple (Ananas comosus)
}

\author{
Bianca Chaves Martins ${ }^{1 *}$, Robson Rescolino ${ }^{1}$, Diego de Freitas Coelho², Foued Salmen Espindola', \\ Beatriz Zanchetta ${ }^{2}$, Elias Basile Tambourgi ${ }^{2}$, Edgar Silveira ${ }^{2}$ \\ From 5th Congress of the Brazilian Biotechnology Society (SBBIOTEC) \\ Florianópolis, Brazil. 10-14 November 2013
}

\section{Background}

Bromelain is the generic name given to the set of derived endopeptidases belonging to members of the Bromeliaceae family, which belongs to the pineapple (Ananas comosus), being able to break the peptide bond, separating proteins and amino acids [1]. Bromelain possesses a wide range of therapeutic benefit as property of facilitating digestion of proteins, meat softening, ability to facilitate blood clotting [2] And economic importance related to the food industry and textiles and production of drugs resulting in an increase of its value [3]. Thus, the aim of this work is to evaluate the stability of the enzyme in relation to different temperatures and $\mathrm{pH}$ to make feasible the purification of the same.

\section{Methods}

The enzyme extract was obtained from the peel, stem and leaves of (Ananas comosus). The plant tissue derived from the peel, stem and leaves of pineapple were processed extractor and then centrifuged at 10,000 g for 20 minutes at $4{ }^{\circ} \mathrm{C}$ to remove insoluble material. For the assay of enzymatic activity was used azocasein method, wherein azocasein 1,0\% (w / v) (Sigma) was solubilized in ethanol $4 \%(\mathrm{v} / \mathrm{v})$ and $0.1 \mathrm{M}$ phosphate buffer, $\mathrm{pH} 7.0$, and used as a substrate. The assay mixture, containing $125 \mu \mathrm{L}$ of substrate and $125 \mu \mathrm{L}$ of enzymatic extract was incubated for 10 minutes at $37^{\circ} \mathrm{C}$ and the reaction stopped by adding $750 \mu \mathrm{L}$ of trichloroacetic acid $5 \%(\mathrm{w} / \mathrm{v})$. The samples were centrifuged at $4000 \mathrm{~g}$ for 10 minutes and at a temperature of $5^{\circ} \mathrm{C}$. The stability of bromelain was evaluated against various pHs (5.0, 6.0, 7.0, 8.0, and 9.0 and 10.0) and at different temperatures $(5,25,35,40,45,50,55$ and $60^{\circ} \mathrm{C}$ ). And readout was taken in a spectrophotometer at
$440 \mathrm{~nm}$, and a unit of activity was defined as the amount of enzyme required to produce an increase in optical density by one unit at an interval of one hour.

\section{Results and conclusion}

The enzyme activity increased with increasing temperature until it reaches $50^{\circ} \mathrm{C}$, where it began to decline rapidly. Front $\mathrm{pH}$ changes, the activity increased to $\mathrm{pH}$ 7.0, where declined with the change of the same, raising and exhibiting a second peak of activity at $\mathrm{pH} 10.0$. The optimum temperature and $\mathrm{pH}$ for activity was $50^{\circ} \mathrm{C}$ and $\mathrm{pH} 7.0$, in which one observes the greatest activity of the enzyme bromelain. Thus, it was concluded that for this study the enzyme stability is interesting to work with these conditions.

\section{Authors' details}

${ }^{1}$ Universidade Federal de Uberlândia, Uberlândia, Brazil. ${ }^{2}$ Universidade Estadual de Campinas, Campinas, Brazil.

Published: 1 October 2014

References

1. Souza OP, Coutinho AC, Torres TLR: Avaliação econômica da produção do acabaxi irrigado cv Smooth Cayenne no Cerrado, em Uberaba-MG. Revista Universo Rural 2010, 30(1):00-00.

2. Abílio GMF, Holschuh HJ, Bora PS, Oliveira EFD: Extração, atividade da bromelina e análise de alguns parâmetros químicos em cultivares de abacaxi. Revista Brasileira de Fruticultura 2009, 31:1117-1121.

3. Coelho D, Barbosa SA, Silveira E, Souza RR, Tambourgi E: Biosurfactant Production from Unconventional Resources: a Short Overview. International Review of Chemical Engineering 2012, 4(2):175-183.

doi:10.1186/1753-6561-8-S4-P137

Cite this article as: Martins et al:: Studies of stability and characterization this enzyme bromelain in pineapple (Ananas comosus). BMC Proceedings 2014 8(Suppl 4):P137.

${ }^{1}$ Universidade Federal de Uberlândia, Uberlândia, Brazil

Full list of author information is available at the end of the article 